Revue bibliographique pour le domaine irano-aryen

\title{
Michael Shenkar. Intangible Spirits and Graven Images: The Iconography of Deities in the Pre- Islamic Iranian World
}

\section{Samra Azarnouche}

\author{
(2) OpenEdition \\ Journals \\ Édition électronique \\ URL : http://journals.openedition.org/abstractairanica/43657 \\ DOI : 10.4000/abstractairanica.43657 \\ ISBN : 1961-960X \\ ISSN : 1961-960X \\ Éditeur : \\ CNRS (UMR 7528 Mondes iraniens et indiens), Éditions de l'IFRI
}

\section{Référence électronique}

Samra Azarnouche, « Michael Shenkar. Intangible Spirits and Graven Images: The Iconography of Deities in the Pre-Islamic Iranian World », Abstracta Iranica [En ligne], Volume 37-38-39 | 2018, document 7, mis en ligne le 30 décembre 2018, consulté le 28 septembre 2020. URL : http:// journals.openedition.org/abstractairanica/43657 ; DOI : https://doi.org/10.4000/abstractairanica 43657

Ce document a été généré automatiquement le 28 septembre 2020.

Tous droits réservés 


\title{
Michael Shenkar. Intangible Spirits and Graven Images: The Iconography of Deities in the Pre- Islamic Iranian World
}

\author{
Samra Azarnouche
}

\section{RÉFÉRENCE}

Michael Shenkar. Intangible Spirits and Graven Images: The Iconography of Deities in the PreIslamic Iranian World. Leiden-Boston: Brill, 2014, xxii+392 p. (Magical and Religious Literature of Late Antiquity 4), app., index, bibl., ill.

1 Issu d'une thèse de doctorat préparée en 2013, cet ouvrage fournit un large répertoire des représentations des divinités iraniennes provenant d'Iran et d'Asie centrale, des différentes périodes du monde iranien préislamique (les empires des Achéménides, des Parthes et des Sassanides, l'empire kouchan et ses successeurs).

2 Après une introduction soulignant la rareté du matériel iconographique par rapport au Proche-Orient ou à l'Antiquité classique (p. 1-9), l'A. donne au $2^{\mathrm{e}}$ chapitre un aperçu des sources textuelles: les inscriptions épigraphiques, l'Avesta, les sources gréco-latines, les sources chrétiennes, le Talmud de Babylone, la littérature zoroastrienne en moyenperse, les sources chinoises, les sources médiévales en arabe et en persan et enfin le Shāhnāme (p. 11-45). Le chapitre 3 " panthéon iconographique " (p. 47-174) présente 29 représentations divine anthropomorphes, dont 21 divinités avestiques, auxquelles s'ajoutent Ayra Mainiiu et Yima - dont le statut divin est spécifiquement centrasiatique-, Mozdooano, dieu exclusivement kouchan (dieu tribal ou ancêtre divinisé ?), Nana, Oxus, une déesse scythe anguipède et un ensemble de six dieux non identifiés. Ainsi, il n'est pas tenu compte des groupes divins, tels que les Frauuaș̄i ou les Aməș̆a Spəṇta en tant qu'heptade. 
Empruntant la terminologie de Mettinger $(1995,2006)$ sur l'aniconisme biblique, le chapitre 4 (p. 175-179) reconnaît dans la représentation iranienne à la fois l'aniconisme matériel (pierres levées), l'aniconisme du vide (char vide) et l'aniconisme élémentaire (feu), mais aussi le symbolisme zoomorphique. Le chapitre 5 (p. 181-188) analyse la question de l'anthropomorphisme iranien qui se distingue par une grande asymétrie entre l'est (présence bien établie de statues de culte) et l'ouest (culte parfois aniconique mais sans être iconoclaste). Les reproductions des figures (189 illustrations en noir et blanc (p. 237-365) et 32 planches en couleur (p. 369-392)) sont d'une excellente qualité. Outre la mise en doute de plusieurs des interprétations établies par le passé, l'objectif premier de ce livre - dont le mot d'ordre semble être "prudence» - est de montrer contre certaines idées reçues l'existence d'une iconographie religieuse iranienne riche, éclectique et inventive, loin de se limiter à une vision avestique.

\section{AUTEURS}

\section{SAMRA AZARNOUCHE}

EPHE, Mondes iranien et indien, Paris 